\title{
Iraqi e-government and cloud computing development based on unified citizen identification
}

\author{
Thulfiqar Abd', Yaqeen S. Mezaal' ${ }^{2}$, Mustafa Sahib Shareef ${ }^{3}$, Shahad K. Khaleel ${ }^{4}$, Hadi Hussein Madhi ${ }^{5}$, Seevan \\ F. Abdulkareem ${ }^{6}$ \\ ${ }^{1}$ Al Muthanna University, Al-Muthanna, Iraq \\ ${ }^{2}$ Medical Instrumentation Engineering Department, Al-Esraa University College, Iraq \\ ${ }^{3}$ Al Muthanna University, Al-Muthanna, Iraq \\ ${ }^{4}$ Medical Instrumentation Engineering Department, Al-Mansur University College, Iraq \\ ${ }^{5}$ Medical Instrumentation Engineering Department College of Nursing, Misan University, Iraq \\ ${ }^{6}$ Computer Technology Engineering Department, Al-Mansur University College, Iraq
}

\begin{abstract}
In this paper, besides an overview of e-Government and cloud computing services in Iraq, an applied survey to establish relevant prospects of the Iraqi citizens for e-Government and cloud computing services was adopted. Moreover, to study the potential putting into practice of e-Government and cloud computing services based on citizen identification in Iraq. Based on survey results, 112 different e-Services were proposed by qualified Iraqi citizens. The requested e-Services were highlighted based on a provided statistical list in this paper. This paper can be an essential step to enhance e-Government and cloud computing functionaries in Iraq consistent with the citizen's outlooks and discover technical and nontechnical barriers that delay the development of Iraqi e-Government and cloud computing.

Lastly, the accomplishment of e-Government and cloud computing imposes several essential tools as in Information and Communication Technology (ICT). The development scheme in this paper involves three years to improve the Iraqi e-Government database and offer the advantageous capability of ICT to all responsible persons and citizens based on Standard Materials and International Certificates.
\end{abstract}

Keywords: $\quad$ Iraqi E-Government, Cloud Computing, ICT, Unified Citizen Identification.

\section{Corresponding Author:}

Yaqeen Sabah Mezaal

Medical Instrumentation Engineering Department,

Al-Esraa University College,

Baghdad, Iraq.

E-mail:yakeen_sbah@yahoo.com

\section{Introduction}

\subsection{E-Government}

The term of electronic government (e-Government) can be understood from the fundamental purpose of ICTs to provide online services through the web. The activities of e-Government can be interrelated with state agencies, businesses, and citizens [1].

Besides, e-Government promotes the reform agenda (modernization the governance of science and technology) so that the government and its policies are being more productive. The main goal of eGovernment is to increase the use of networked digital information, including innovative design automation of 
standard processes in other targets. The improved efficiency will enhance the quality of service and the goal to fulfil more effectual results in new services and better functional abilities [2,3]. Another good obsession with e- Government is decreasing the gap among citizens and the government that toughens democracy. Consequently, the final service releases by ICT additionally improve the association between government and citizens or businesses. Furthermore, e-Government services make the government have more clarifications with the assistance of laws (such as information acquisition law). Public records will be reachable by the citizens to be observed and contributed to e-Government.

E-Government can also be described as the application of ICTs to promote the deliverance of governmental services based on service quality enhancement and integrate government and its services for citizen, business, and other government agencies and facilitating citizens to use government information to get services wherever and whenever they would like over multiple channels using the internet websites [4].

E-government is not limited to putting government forms on government websites. It is about using ICTs to its fullest to provide services and information that is centred on citizens. As ICT has verified to be a wellorganized technique of accomplishing different services between the government, its citizens, business communities as well as within the public management itself. Nag argues in [4] that it brings numerous categories of government services closer to citizens and enables the delivery of services to citizens and businesses on their terms and at their convenience rather than following the logic of internal government structures.

E-Government also facilitates to construct/regain confidence between government and citizens because ICT can enable citizen engagement in the policy process by transparency, and hence prevent corruption for a sponsored, open, and accountable government. Some instances of trendy services include government levies and corporation tax payments, new company registration, personal application forms such as passport, driver's license, and employment search services [5]. Namely, e-Government represents the permanent expansion of service delivery, population contribution, and governance by transferring various relationships internally and externally through the internet and modern media. This involves government to citizen (G2C), government to employee (G2E), government to business $(\mathrm{G} 2 \mathrm{~B})$, and government to government $(\mathrm{G} 2 \mathrm{G})$, as the types of service delivery [6].

The main goals of e-Government can fall into four main clusters: businesses, citizens, employees, and other governments and public agencies, as shown in Figure 1. The electronic operations and interfaces between the government and each cluster comprise the e-Government web of associations and the relevant four significant e-government types service delivery as well as Non Governmental Organizations (NGOs) in the civil society.

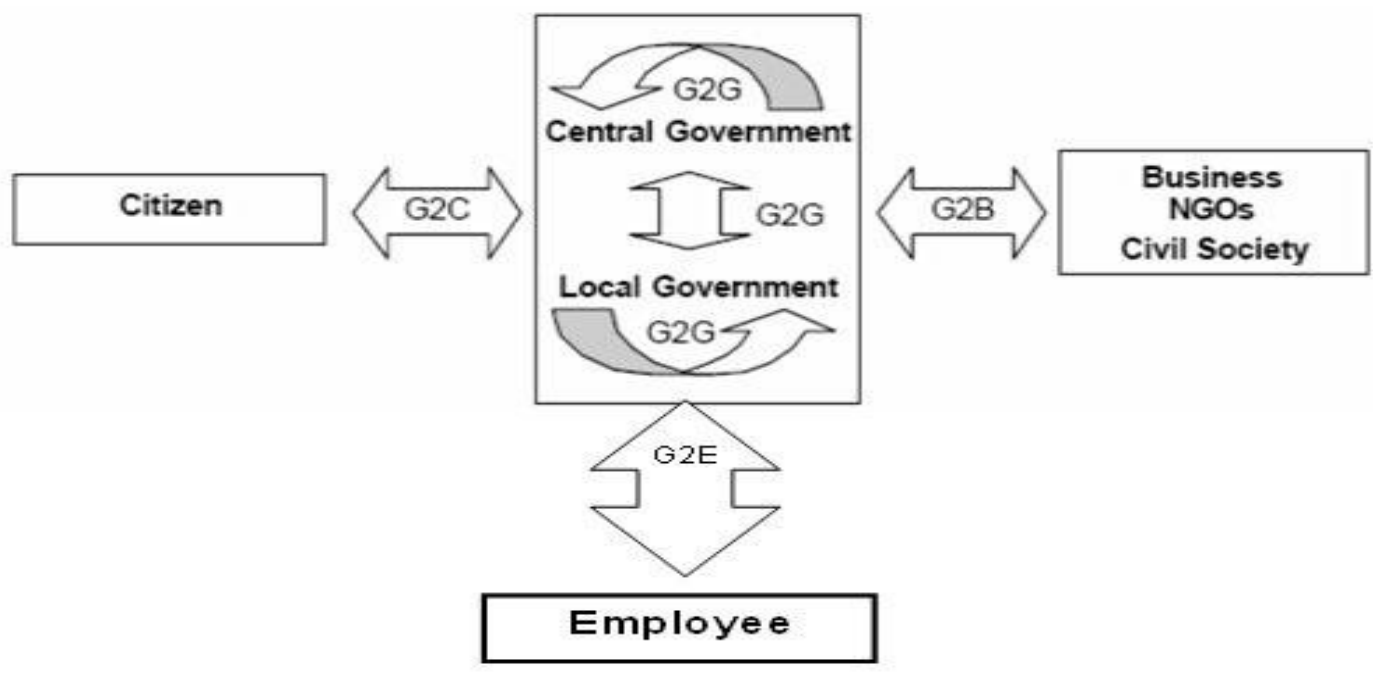

Figure 1. Types of e-Governments delivery models 


\subsection{Cloud Computing}

There are numerous possible explanations for cloud computing terms. The majority of them concentrate on technological issues only. Cloud computing can be defined as a massive collection of various hardware, software, and other services that can be managed via the "cloud" environment. The entire resources of them can be accessed at any time and anywhere as needed. Generally, the cloud provider sells his service based on pay-per-use. Namely, it indicates that there is massive flexibility in the adoption of these services as additional resources that are always accessible.

This technology is the most overvalued and efficient tool used in all sections of engineering, business, and other sciences to boost the capability or insert capacities with dynamism, with no supplying any new infrastructure [7].

Various transactions of commerce and industry are presently utilizing computing cloud computing resources, which have been classified as one of the ten leading technologies of the 21 st century. It has been predictable that the worth of the cloud computing market is going to boost from $\$ 40.7$ billion to $\$ 240$ billion from 2010 to the 2020 year ranges. Cloud computing has promising features to distribute IT services, and its enormous importance is analogous to the importance of electricity, telecommunications, and water. It is also a facilitating tool to make available computing resources to hold up other technologies and applications as in the Internet of Things and mobile computing. Considering cloud computing into account changes not merely the adopted technology by an enterprise but also the approach in which business transactions are handled. Additionally, transforming enterprise resources into a cloud environment engages decision making at the tactical, strategic, and outfitted levels, and prospectively impacts all organizational aspects [8]. After the 2020 year, some forecasting statistics confirm that the cloud computing fiscal benefits will be greater than $\$ 240$ billion due to permanent cloud platform expansions and enabling new business models and innovative services [9].

The virtualization, rapid elasticity, broad network access, and superior performance of cloud services are the most critical factors to make this technology enormously rising continuously. With customary "off-the-shelf" software packages, an application is typically established on the corporation's foremost server, and then on every computer in the workplace all over the organization [7].

The dominant notion of cloud computing originated around the 2004-2005 year. Formerly, the cloud symbol was represented the Internet concept before 1994. In 2006, when Amazon Web service (AWS) was primarily initiated a utility computing source, the fundamental nature of cloud computing had been begun for the industry. The scheme of an "intergalactic computer network" was set up in the 60s by J.C.R. Licklider, who was in charge of facilitating the expansion of ARPANET (Advanced Research Projects Agency Network) in 1969.

Accordingly, cloud computing is somewhat new to the literature. Generally, it has been initiated beyond the 90s, and it has been more improved after the millennium stage. The name of the cloud had been created for the reason that the sent data could not be tracked anymore when moving towards its destination. In the past years of cloud computing, the Amazon association was dynamic in the field of cloud computing. This association was previously a substantial investing society in cloud computing, including massive data centers, which usually merely employ eight to twelve percent of its computing power. The remaining computing power was held in reserve for compulsory peak usage. Amazon association launched cloud computing to save expenditures in these large data centers. In the year of 2006, the Amazon association started to supply cloud computing for customers all over the world. Subsequently, Google and IBM have shown a significant weight for cloud computing and begun to invest it as a potential and promising tool in the field of information technology $[7,8]$.

In this paper, as compared with other studies, an important overview of e-Government and cloud computing services in Iraq with an applied survey to create relevant prospects of the Iraqi citizens for e-Government and 
cloud computing services have been adopted. Additionally, it aims to investigate specifically the potential enhancement of e-Government and cloud computing services based on citizen identification in Iraq in governmental and private sectors.

\section{Iraqi E-government and Iraqi Identification System}

The Iraqi authority is in the sensitivity levels of expanding an e-Government scheme in an atmosphere that depends on pioneering inspirations; these inspirations will initiate impulses toward a positive and prosperous future [10]. Because of the bad security situations since 2003, Iraq realizes itself toward special conditions with how to go forward to be in the way of development.

In June 2004, the United Nations asked the Member States to assist the new Iraqi government in enhancing its building and institutions. The Iraqi Minister of Science and Technology and Italian Minister for Innovation and Technologies sign a memorandum to offer financial and technological experiences in building a suitable architecture of an Intranet connecting the Ministries of the new Iraqi Administration and construct an e-Government project. The government intranet project stands for the preliminary action for the construction of a stylish e-Government environment to maintain the rebuilding of the infrastructure of Iraq. United States Agency for International Development (USAID) and the Iraqi Ministry of Science and Technology put a strategy from 2007-2010 to develop the Iraqi e-Government project, as shown in Figure 2. The strategy of e-Government will have the best result chances if the process progresses, go with a high level of funding and sponsorship [10,11].

\section{Pathway to eGovernment in Iraq 2007-2010}

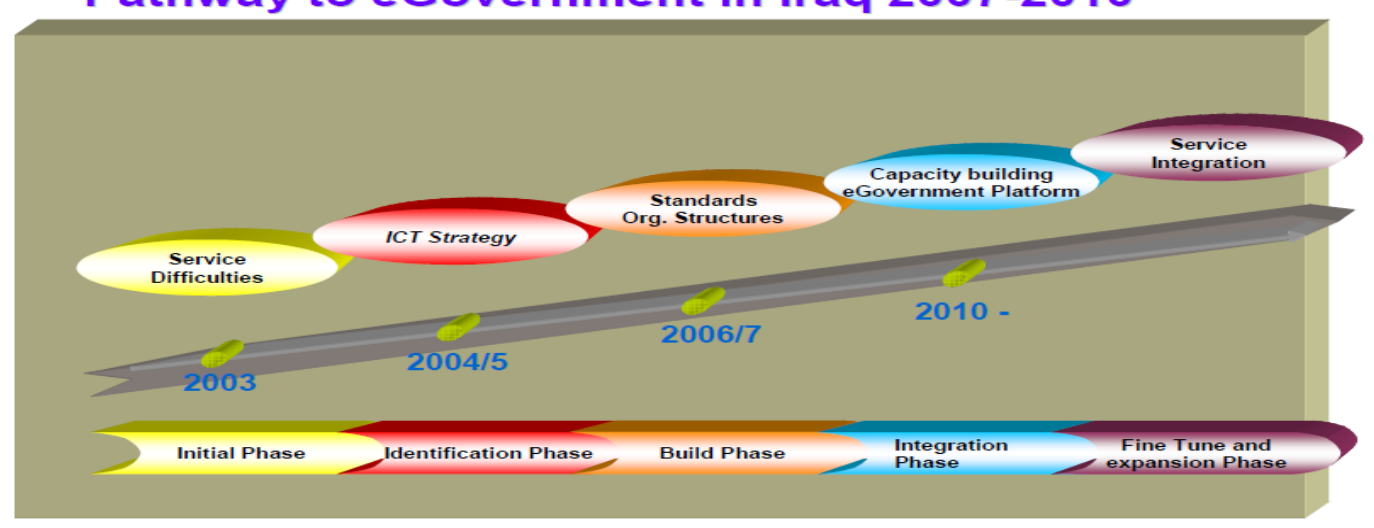

Figure 2. E-Government progress and pathway in Iraq 2007-2010

A government sector is always receiving essential services and enhanced opportunities for community participation. Nevertheless, still, several challenges exist during the development and implementing process [12].

Accordingly, the Ministry of Science and Technology and the Ministry of Communication have positioned pre-steps for establishing the infrastructure of e-Government in Iraq with the aid of USAID since 2004. These ministries declared that the stage after the year 2010 would represent the communication network achievement in Iraq for e-Government project preparation to provide various services to citizens and public organizations [13].

The major obstacle to initiate the accomplishment of e-Government in Iraq is the insufficient unified national ID registry system. In order to give the best services for the citizen, the service supplier has to distinguish who they are serving primarily. There should be several system sorts to classify who they are. Currently, Iraq does not possess appropriate identification document archiving of its citizens. At present, there is just a single database in possession of the Ministry of Trade, which had been established before more than 
25 years with the aid of the United Nations oil-for-food program in the 1990s [14]. This database has been used for two essential reasons, firstly to distinguish recipient for monthly food rationing and secondly for the election processes. The recipient identification system in this database identifies family regardless of the individual citizen. So, each identification card has the head of the family name and family members. The distinctive property of the identification card is its unique family number. The objective of this combination was to issue the unified Food Ration Card.

After the war on Iraq in 2003 and the destruction of the previous regime, the Directorates of Passports and Residency had been affiliated to the Nationality Directorate. They renamed later as General Directorate for Nationality [15].

The transaction process of information handling at the General Nationality Directorate in Iraq intensely depends on manual procedures. This manual paper documentation is overwhelmed by a lot of weakness points. Among these are; occupy many physical storage spaces, which also initiate complexity in ensuring its reliability and privacy. Also, it has imperfect mobility, complicated to be fixed and restored. Furthermore, the data distribution among numerous ministries would be tiresome and chaotic.

At present, under the scheme of Iraqi e-Government, the majority of existing identification by the Government Interoperability Framework has verified the citizen initiative, as stated in Table 1 [14].

Table 1. The current citizen data scheme [14]

\begin{tabular}{|c|c|}
\hline Civil Affairs ID & Birth Date \\
\hline Citizenship Certificate ID & Birth Place \\
\hline Resident Card ID & Biometrics -Photograph \\
\hline Ration Card ID & \\
\hline $\begin{array}{c}\text { Name as Three Parts (First } \\
\text { Name, Father Name, Grand } \\
\text { Father Name) }\end{array}$ & \\
\hline Gender & \\
\hline Mother Name & \\
\hline Marital Status & \\
\hline Name of Spouse & \\
\hline Full Address & \\
\hline
\end{tabular}

\section{Cloud Architecture}

It is confused architecturally to understand how cloud is equivalent to and dissimilar from accessible models of computing and how these equivalencies and dissimilarities affect the managerial, operational, and technical segments to network and information security practices. There are mainly three foremost groups of cloud employment models, as in Figure 3, including Public Cloud, Private Cloud, and Hybrid Cloud. Nevertheless, there are several particular clouds used for marketable purposes as in Community cloud and mobile cloud [7, 8]. 


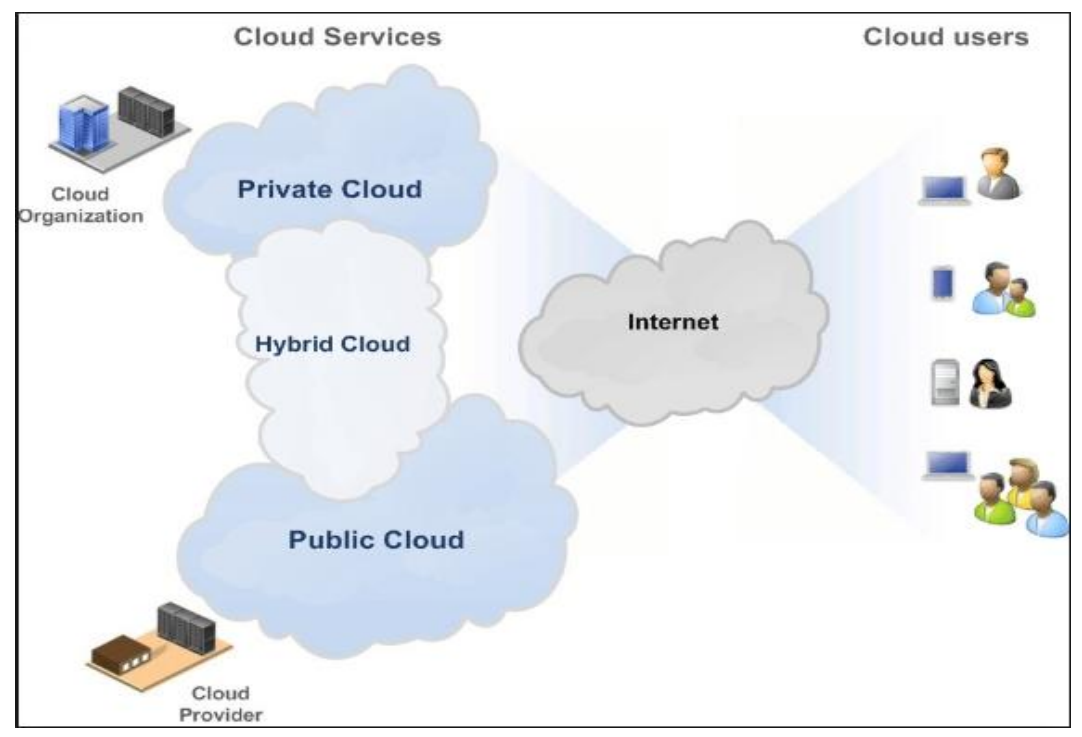

Figure 3. Essential architecture of cloud

Public cloud architecture represents storage, and other resources are used by the universal community by a service supplier, without charge to all services or a pay per use model.

Private cloud infrastructure is run exclusively for a particular association, whether controlled internally or by a third-party and hosted inwardly or outwardly.

Some associations can host vital applications based on private clouds with somewhat fewer security issues on the public cloud. Hybrid cloud computing combines private and public cloud types. This is an integration of two or more clouds (private, community, or public) that are remained as distinctive entities. However, they are bounded jointly, presenting the advantages of numerous deployment models.

A community cloud in computing stands for a collaborative effort in which infrastructure remains shared among some organizations from a specific community with shared concerns ( compliance, security, jurisdiction, etc.), whether achieved internally or by a third-party and hosted externally or internally. The costs can be spread over a smaller amount of users than a public cloud but higher than a private cloud. Consequently, just several cost savings potential of cloud computing are grasped. Community cloud stands for a distinct kind of service where a group of service suppliers united together and form a community based on service type.

Mobile cloud computing stands for the practice of cloud computing to be combined with mobile devices. It is existent as data and transactions are reserved on the Internet more willingly than on device entities, given that on-demand right of entry. The applications of the mobile cloud are managed on a remote server and then transferred to the user. These applications are a speedily new segment of the international mobile marketplace.

\section{Cloud-Based on Delivery Models}

Cloud computing servers set up three services classified principally into three models that are Infrastructure as a service (IaaS), Software as a service (SaaS), and Platform as a service (PaaS), as illustrated in Figure 4. IaaS is the deliverance of computer infrastructure characteristically a platform virtualization surroundings as a service. This fundamental model of cloud service offers computers and other resources as substantial or mostly as virtual machines. While SaaS conveys programs to millions of clients throughout the browser, it is regularly used in individual resource organization systems and Enterprise Resource Planning(ERP). Yahoo and Google are application examples that provide this service category. Lastly, PaaS offers a framework as a service layer depending on which software applications can be steadily and dependably built. Industry Analyst firm Forrester depicts PaaS as an outwardly hosted service that offers a 
comprehensive scheme to generate, manage, and activate applications. Various instances of PAAS can be found in Cloud Foundry, Google App Engine, Microsoft Azure, Amazon Elastic Beanstalk, Engine Yard, Mendix [7, 8].

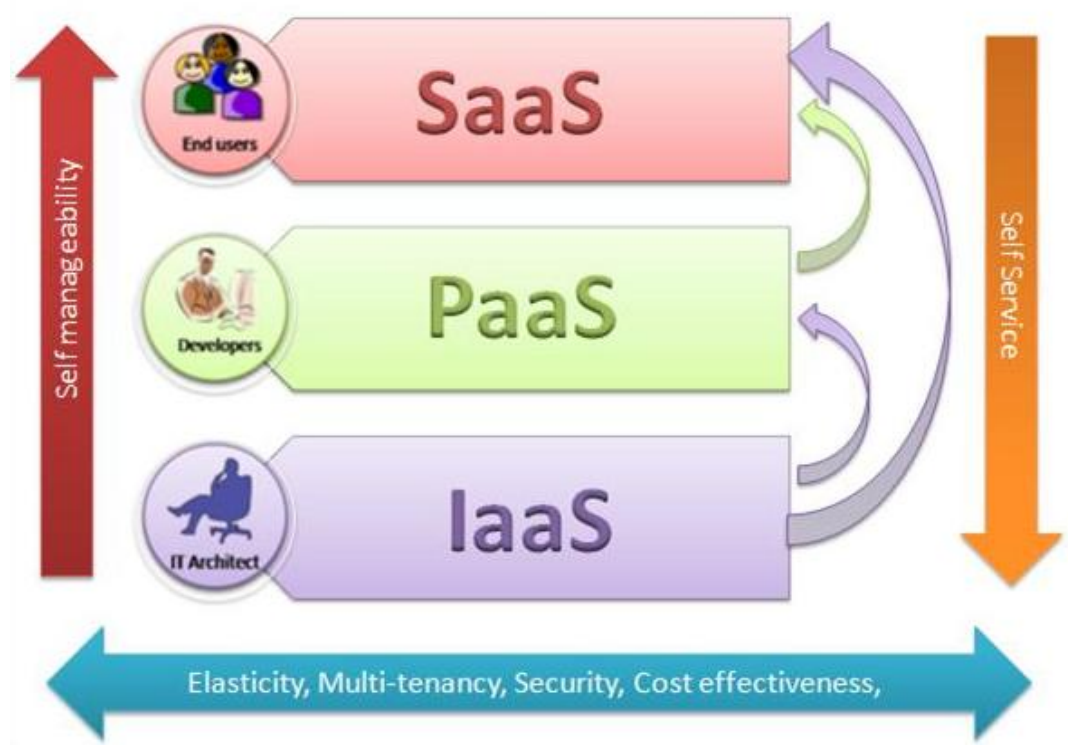

Figure 4. Delivery models of cloud services

\section{Cloud computing in Iraq}

In the case of Iraq, the advances of E-Governance and cloud technology are still meager. However, According to the United Nations E-Government Survey in 2012 [16], Iraq has an Implementation rate of 25\% of planned e-Government online services. We perceive there is a better set up of e-Government processes than cloud computing projects, which is, until now, not up to the ambition level. This section gives a survey on egovernance as well as the cloud in Iraq since cloud-based e-government has numerous gains to an organization like less distributed data storage, cheaper resources availability, more security control, more scalability, and responsibility. Therefore, surveying e-government in Iraq is imperative since there is not lousy initiation in this concern as compared with the current status of cloud technology, which is currently not up to the mark.

For instance, in [17], Wahsh and Dhillon performed an empirical study about applying cloud computing for e-governance in Iraq. The findings of this study demonstrate that technology readiness and trust have no noteworthy weight on e-government adoption via cloud computing. In a broader viewpoint, non-technological factors necessitate further consideration than technological factors.

In [18], a cloud prototype project for the University of Technology (UTC) in Iraq has suggested. This project facilitates e-services and applications to be accessible through a web site page like Google Drive or Microsoft Office. This project assists Iraqi universities as a solution to decrease the expenditure of information technology constraints, time provision, and ease to use for higher education in Iraqi institutions.

In [19], the study has been explained the social and technological factors to adopt cloud technology in educational institutions in Iraq. Their conceptual model and the scientific survey was based on a unified theory of acceptance and use of technology (UTAUT). This study has been conducted through academic staff, students, and non-academic staff of Kufa University in Iraq using stratified sampling procedures. 
Mohamed S. Al-Khayat et al., suggested a standard model of cloud computing platform with six service layers to hold up the higher education colleges and institutions of Iraq to be capable of applying a learning cloud computing visibly, straightforwardly and moving them out of the whirlpool of modernizing and sustaining their infrastructure [20].

Muzhir Shaban Al-Ani et al. suggested a well-organized cloud background for the Iraqi ministry of higher education and scientific research. The used technique is reliant on several accesses that could take place from universities in the ministry. Duplicate data and applications can manage the load in some servers set up in the center, east, west of Iraq. The load, as well, can be restricted by signifying the use of load balance and routing protocol algorithms [21].

In [22], ITS (intelligent transportation systems), C2C (car to car), C2I(car to infrastructure), and VANETS (vehicular ad hoc network) terms have been exploited using mobile and Cloud computing technologies. They presented an intellectual disaster managing system. This disaster managing system structural design and components have been illustrated and determined by modeling and simulations, and its effectiveness has been displayed in terms of improved disaster evacuation characteristics in Ramadi city in Iraq.

\section{The applied survey}

The required data for e-Government services gateway can be accumulated by the interview or questionnaire procedures that can be used firstly to dialogue with employees, experts, and students liable for the development and accomplishment of e-Government. These methods are necessary for analyzing the related information by using Domain Analysis to meet points on cultural background, explaining societal circumstances and intellectual patterns within it as well as to observe the semantic relationships. Additionally, to assemble data by feedback survey method from Iraqi citizens. Subsequently, investigating the collected information by the survey through the deductive statistics to assess the elements rate and weigh up the eGovernment and cloud computing services in Iraq after getting the more competent and flexible gateway to be adopted by various users of Iraqi society.

To achieve a good reaction, the questionnaire has been concentrated on the selected respondents. The proportion and consistency of questions have been preserved by sequencing the questions consequently. The required terms have been clarified sufficiently. We began by asking respondents about the usage of the internet because e-Services are chiefly related to internet networks. So, this is essential to recognize the frequency level of internet usage.

The $2^{\text {nd }}$ question is an unrestricted question that facilitates us to collect diverse ideas and suggestions about the required e-Services by the Iraqi government. These ideas will enable us to restrict the significance of eServices in the social sector.

Of course, there are obstacles and difficulties at all expansion procedures in any project initiation. In 3rd and 4th inquiries, these difficulties in realizing the e-Services of Iraqi e-Government and cloud computing have been inquired.

The $5^{\text {th }}, 6^{\text {th }}$, and $7^{\text {th }}$ inquiries are on the subject of the existing situation of e-Services in Iraq. These inquiries are interconnected to each one. The survey has been submitted to IT educated individuals; therefore, it is necessary to inquire about e-Services usage level and their suggestions about providing more e-Services by the Government of Iraq.

The $8^{\text {th }}$ inquiry is the central core of this survey. Respondents are asked about the leading Iraqi ministries in the e-Services field as well as activities or e-Services they are concerned as active tools of the e-Government and cloud computing. 
The $9^{\text {th }}$ question is intended to provide the opinions and comments from each respondent about the available e-Services in Iraq.

The $10^{\text {th }}$ inquiry is about personal data of respondents, including their contact details and age group.

We have chosen people group of age from 21 to 40 years. All of them are enough qualified to answer about the assigned survey. The respondents of the survey consist of students and experts who have attentive development about the management of information in the field of e-Government and cloud computing. The survey has been distributed through emails and social links because it is a more straightforward and more rapid way to be in touch with them. The survey section is shown in Appendix 1.

\section{Survey result}

For the assigned survey, our contacts, special online groups, and confident social links from Iraq have been used. Five hundred requests were sent to confident Iraqi citizens to answer the survey questions. There were just one hundred replies. Consequently, as it can be observed from Figure 5, just 20\% of responses had been obtained, although reminding messages and e-mails had been sent to get the most significant response. However, this low rate of replies was satisfactory and included significant suggestions.

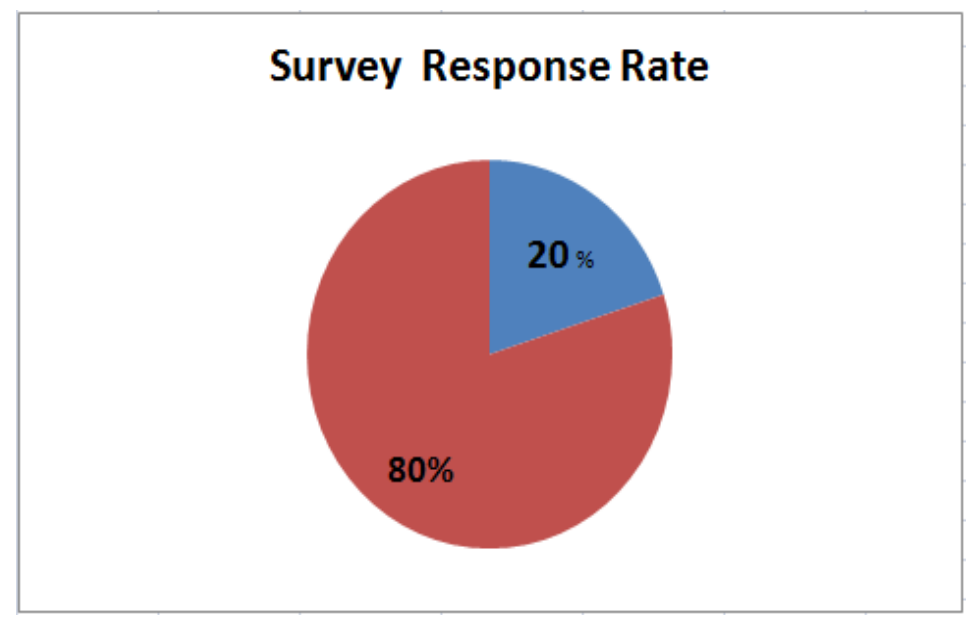

Figure 5. Survey responding rate

This study is not aimed to present a full depiction of the real prerequisites of e-Services prospects in Iraq. It presents a summary of e-Services prospects from specific segments of the Iraqi community.

The survey results present 100 responses to each question by these respondents. The description of the response aligned with each inquiry, which depicts diverse details, has been done.

For the first question, most respondents (91 persons) use the internet daily while others use the internet alternatively. The majority of respondents showed the e-Services necessity in reducing the required time, resources, and money as a result of the effectiveness increasing and connection between the government and citizens. This explains the future ambitions of those respondents on the way to renewed online usage. The respondents indicated various types of obstacles in the progress of e-Services, such as lack of awareness and education, security, unsatisfactory electricity, and low bandwidth internet. However, there are many eServices which are existing in e-Government of Iraq, and 80 respondents use these e-Services when they required. However, these available online services are not based on unified citizen identification.

These services can be used for job applications, ID card issuance, bank services, license information, voting results, and online bill payments. There were no usages about e-Services by 18 respondents of the survey. Every one of the respondents confirms a considerable level of hope for developing further online services in Iraq. Accordingly, a total of 112 e-Services have been proposed by these respondents according to their daily 
routines and the most familiar needed online services, as shown in Table 2. These service demands can excite more enlargement procedure of e-Government and cloud computing in Iraq.

Table 2. Various e-services suggested by iraqi respondents for the assigned survey

\begin{tabular}{|c|c|c|c|}
\hline Service \# & Classification & Class of Service & Suggestions \\
\hline & Education & & \\
\hline 1 & Online Exams & $\begin{array}{l}\text { Interactive, } \\
\text { Transactional }\end{array}$ & 5 \\
\hline 2 & $\begin{array}{ll}\text { Online } & \text { Library } \\
\text { Browsing } & \end{array}$ & Informative & 10 \\
\hline 3 & Seeing Exam Results & Informative, Interactive & 7 \\
\hline \multirow[t]{2}{*}{4} & $\begin{array}{l}\text { Enrolment in Higher } \\
\text { Education }\end{array}$ & $\begin{array}{l}\text { Interactive, } \\
\text { Transactional }\end{array}$ & 8 \\
\hline & Taxation & & \\
\hline \multirow[t]{2}{*}{5} & Paying Taxes Online & Transactional & 2 \\
\hline & Utility Bills & & \\
\hline \multirow[t]{2}{*}{6} & Paying Bills & Transactional & 3 \\
\hline & $\begin{array}{l}\text { ID Cards and } \\
\text { Passports }\end{array}$ & & \\
\hline \multirow[t]{4}{*}{7} & $\begin{array}{l}\text { ID Cards and Passports } \\
\text { Issuance }\end{array}$ & Transactional & 3 \\
\hline & $\begin{array}{l}\text { ID Cards and Passports } \\
\text { Renewal }\end{array}$ & Transactional & 3 \\
\hline & $\begin{array}{l}\text { ID Cards and Passport } \\
\text { Information }\end{array}$ & Informative & 1 \\
\hline & Jobs & & \\
\hline 8 & $\begin{array}{ll}\text { Online } & \text { Job } \\
\text { Applications } & \\
\end{array}$ & $\begin{array}{l}\text { Informative, } \\
\text { Transactional }\end{array}$ & 24 \\
\hline 9 & Recruitment Services & Interactive & 30 \\
\hline \multirow[t]{2}{*}{10} & $\begin{array}{l}\text { Job } \quad \text { Information } \\
\text { Service }\end{array}$ & Informative, Interactive & 4 \\
\hline & Banking & & \\
\hline 11 & $\begin{array}{l}\text { Online } \\
\text { Banking Services }\end{array}$ & $\begin{array}{l}\text { Informative, } \\
\text { Interactive, } \\
\text { Transactional }\end{array}$ & 3 \\
\hline \multirow[t]{2}{*}{12} & Banking Information & $\begin{array}{l}\text { Informative, } \\
\text { Interactive, }\end{array}$ & 2 \\
\hline & Iraqi Visa Issuance & & \\
\hline 13 & $\begin{array}{ll}\text { Iraqi } & \text { Visa } \\
\text { Requirements } \\
\text { Information }\end{array}$ & Informative, Interactive & 1 \\
\hline \multirow[t]{2}{*}{14} & $\begin{array}{ll}\text { Online } & \text { Visa } \\
\text { Application } & \end{array}$ & Transactional & 2 \\
\hline & Others & & \\
\hline
\end{tabular}




\begin{tabular}{|l|l|l|l|}
\hline Service \# & Classification & Class of Service & Suggestions \\
\hline 15 & Social Benefits & $\begin{array}{l}\text { Informative, } \\
\text { Interactive, } \\
\text { Transactional }\end{array}$ & 1 \\
\hline 16 & Hajj Applications & $\begin{array}{l}\text { Informative, } \\
\text { Interactive, } \\
\text { Transactional }\end{array}$ & 3 \\
\hline
\end{tabular}

By 21-25 age-group, there were 21 services have been proposed. The highest number of service suggestions is 80, which were given by age-group 26-30, while the number of service suggestions proposed by age-group 31-35 was 11. From age-group 36-40, no response had been found. Consequently, this age-group has been discarded in the study, as shown in Figure 6.

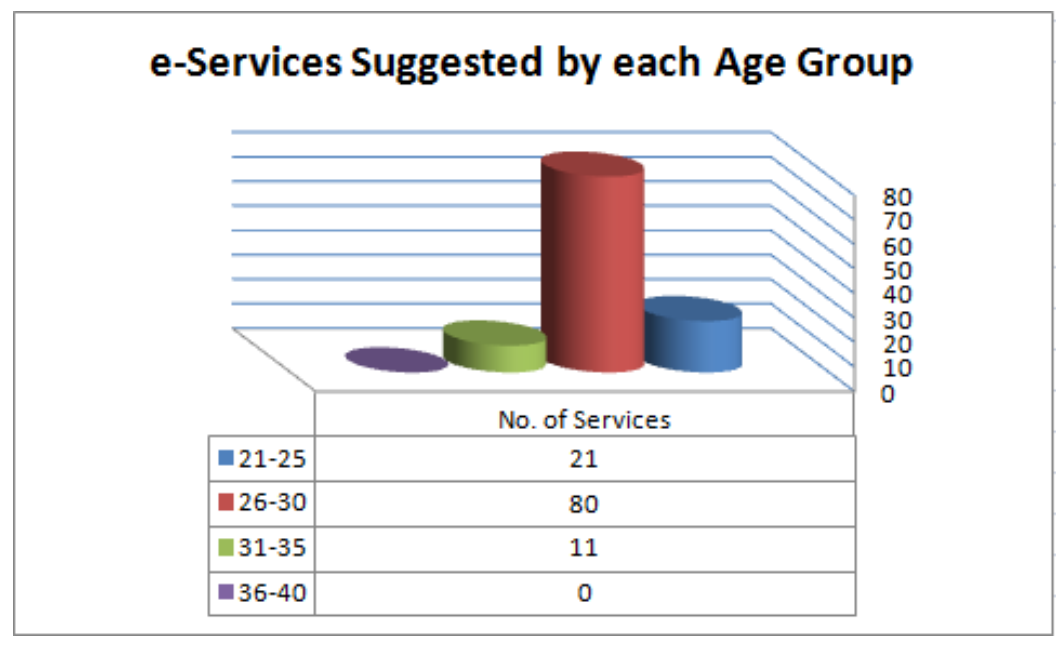

Figure 6. Different age-group participation

The overall collected and summarized information about survey outcomes can be analyzed as follows:

Internet Usage: All respondents have knowledge of internet usage, and $91 \%$ of the respondents use the internet day by day. About $9 \%$ of them are using it instead. This points to the significant ratio of citizens that are using available online services and their worth in the communal sector. New e-Government and cloud computing service requests are demanded.

e-Services essence: All respondents are involved in boosting e-Services. They are familiar with the possibilities of e-Services in saving money, time, and required resources for enhancing the level of eGovernment and cloud computing with satisfactory efficiency.

Barriers: In this research, the barriers and challenges that impede the development of e-Services based on the unified identification system have been recognized in terms of technical issues, political, ICT employees, electricity, and internet connection. These problems are then discussed analytically in the next section of this paper corresponding to the facets of the technology, political, infrastructure, and trained staff for Iraqi eGovernment and cloud computing development.

e-Services Usage: Citizens are unable to specify the personal online service in the Interactive, Informative, and Transactional classifications. Consequently, awareness and accessibility are vital issues. Moreover, the Iraqi government is still offering some elementary e-Services. Following respondent answers, a good ratio of them is utilized from the available online services. About $95 \%$ of the respondents of the survey thought that the Ministry of Science and Technology and Ministry of Higher Education and Scientific Research have the 
most advancements in e-Services areas while the remaining respondents stated their non-knowledge about this issue.

Intention: All respondents have shown the necessity of e-Services from e-Government and cloud computing in Iraq. About $80 \%$ of respondents exploited the available e-Services when they needed while $20 \%$ of them have not used any e-Services.

An overall of 112 e-Services is proposed by every one of the respondents. These e-Services have been collected into 7 of their categories or classifications. These include 16 distinctive e-Services that are presented as Informative, Interactive, and Transactional types in Table 2.

Information e-Service means the mechanisms of the information can be accessed by citizens through eGovernment gateways as in weather forecasting and education-related information services. Interactive eServices are the processes in which the individuals can use e-Services to interact with government agencies as in Recruitment Services and online Hajj applications. Transactional Service is the purchase or sale of services among citizens and governments or other private or public organizations utilizing e-Governments networks.

As can be concluded from this table, some e-Services have the individual classification, while others can be a group of these types. The most requested online services had been from the group of Jobs. There were 58 responses for the e-Service of Job Category, which were mostly proposed by 21-25 and 26-30 age groups. The second most wanted e-Service is the Education category, which had 30 responses from the respondents of the questionnaire.

\section{Challenges and obstructions}

In this research, the barriers that slow down the development of e-government and cloud computing services have been recognized in terms of technical issues, political, ICT employees, electricity, and internet connection. These problems are then addressed into Iraq situations in its e-Government development, according to the facets of the technology, political, ICT staff, infrastructure. All these are explained comprehensively, as shown below:

\section{Technology}

The main technological issues are unsteadiness of infrastructure, corruption, legislative authority, and weak resource administration. In Iraq, there is a distinct lack of Information Technology (IT) knowledge and experience of the government staff. Also, there is a shortage of internal contact between ministries with a fragile consideration basis even within the government and along with the IT administrators. Moreover, there is an inappropriate supervision synchronization in the IT sector. This issue has made a non-physical entity to appear in the sector after its reconstruction and development. As well, the ruling strategies to run information transmission and information distribution are not present. Despite the continued development of the ICT capability building, the e-governance stratagem has not been urbanized until now adequately [23].

\section{Political}

Recently, Iraq and Somalia are considered the only two nations from the Arab homeland that do not have possession of a sufficient unified ID system. Iraq, since 2003, has endured political instability and incongruity. These circumstances are reflected in the Iraqi government's performance in offering services at the entire government agencies. The elemental necessity in facilitating the e-Service deliverance is the unified national ID registry system. Even though the worth of the citizen identification system project comes into sight as second-order within the most critical ten lists of decisive e-Government plan, the advancement in the system achievement has not up till now given serious achievement. It was presumed that the system would be finished in 2009-2010. Nevertheless, regretfully, the system is still unprepared adequately [14, 24]. 


\section{People}

The civil and political conditions in Iraq are not stable as much as necessary for the horizontal adaptation for Iraqi e-Governance and cloud computing. Additionally, the irregularity of the interesting partners and the deficiency of trained employees to direct the e-Government and cloud computing projects are existing. People take part in the influential acts in the e-Government and cloud computing development. Nevertheless, in the Iraq case, it is seriously a huge problem to find enough and a suitable number of persons to be on the project panel. So, the Iraqi government has to concentrate on the matter of the disparity between the persons who are lucky to use the internet and the others who do not. Poor persons with internet usage will be delayed to gain fundamental information technology abilities and computer skills that can supply fiscal prospects. Therefore, they may not enjoy enough allocation of the advantages that e-Government and cloud computing can provide.

E-literacy means the talent and knowledge to deal with technology and computers competently. The individuals who are not e-literacy educated are incapable of being inspired by ICTs since they are not computer educated. Because of the revolution of information technology, there is an extremely actual risk that the whole globe will be classified into the information poor and the information-rich and e-Governance can enable the effectual admittance for the government and its services or amplify the corresponding obstructions $[14,23,25,26]$.

\section{Infrastructure}

The damaged infrastructures are one of the most significant losses after the Iraqi war in 2003. This attributes to communication lines and electric power station problems which can be summarized as follows [14]:

Connectivity: Iraq does not have enough online associations among the agencies. The speed of the internet is relatively low and with restricted access since there is no sponsorship from the government. It has been under the private sector until now. There are no laws to organize the internet connection and also for fax and telephone communications. Iraq following the war in 2003, lost all communication abilities and the current expansion or enhancement in this section are not in the level of ambition.

Electricity: The electricity in Iraq is the most significant barrier that discontinues the entire schemes and projects that require the power to be started. After the war 2003, the electricity in Iraq as yet is not adequate for all requirements. The average hours of electrical power in Iraq are less than 12 hours per day. The majority of agencies used power electricity generators. This represents the hugest difficulty of applying e-Services based on the citizen identification system in Iraq.

\section{The Development Strategies}

The Iraqi government is in the progressing stages of implementing ICT to look up monetary reporting and management information, rationalizing the deliverance of e-Services, improve connection with the community, and provide a mechanism for citizens to interrelate with the government.

The government, from its progress objectives and throughout its education sector and Ministries must necessitate the ICT usage and claim to observe advancement in this public sector from the Governmental Authorities. This demand is significant, especially if ICT is along with the main concern fields in the nation's progressive policies. Decision-makers in the government will be compelled to motivate ICT activities in their countries.

In general, the expansion of Iraqi e-Government and cloud computing requires four essential prerequisites to be applied as follows:

- $\quad$ Modern communication networks.

- $\quad$ Protocols, legal laws, and ethics that govern electronic services.

- The unified national ID is considered an effective mean to protect homeland security, and it is crucial 
for identifying illegal aliens and for protection against illegal immigrants. Therefore, all countries took enormous efforts in its automation and used high bleeding edge technologies and systems to automate ID registry and production to track the registry of residents as well as resident aliens; therefore, the ID is a vital tool to protect national identity.

\section{- $\quad$ Trained Human resources}

In this study, the development of a citizen identification system based on e-government has been proposed through two stages as follows:

1. Developing the E-Governance and cloud computing environments in all Iraqi ministries (24 months): This includes the building of Unified Database based on efficient ICTs.

The author of this research suggests grasping the national abilities represented by General Electronics Systems Company/Iraqi Ministry of Industry and Minerals, which has well-qualified staff in the fields of information and communication technologies [27]. Moreover, they are recently trained in prestigious international workshops and programs. The GSC company has certain cooperations with influential international companies, i.e., International Microsoft Company, which have tremendous experience in the operational software and information technologies. Other liable ministries as in the Ministry of Science and Technology, the Ministry of Industry and Minerals, the Ministry of Higher Education and Scientific Research, and the Ministry of Communications can be contributed with this company as national efforts to achieve this goal.

Of course, these recent national efforts and abilities will reduce the expenses of such a big project from Federal Iraqi Budget. However, these national abilities have not exploited seriously in the construction of the Iraqi e-Government project yet.

On the other hand, the electricity obstacle can be solved by using efficient power generators or dedicating special power stations for each directorate and building in the essential Iraqi institutions.

2. Developing human resources of all Iraqi Ministries: Presently, the government must guarantee that each user has enough units of ICT for practice and supporting ICT activities. The strategy of this stage will require 12 months to afford practical skills of ICT to all liable persons from minister to government staff based on international standards.

It is recommended for the Iraqi government to highlight ICT lectures all over the universities and institutes. The educational syllabuses should contain details of computer and information technology contents according to "Standard Materials and International Certificates", as an essential qualification for undergraduate and postgraduate studies in computer and information technology fields.

The university courses in the areas of e-Government and cloud computing aim to give relevant systematic and realistic knowledge of ICT basics for the students, that can be useful to the public and non-profit sectors.

These above strategies can be monitored and enhanced by designing a gateway of e-Government and cloud computing to realize the difficulties facing the project of the Iraqi identification database system and give details of the mechanism of this gateway and encourage the Iraqi citizens to take advantage of e-Government and cloud computing and raise their self-confidence of online services. Moreover, to know how the building of an online services gateway will be accessible, efficient, and uncomplicated for various users. This will also give the chance to conquer all the difficulties facing the expansion of e-Government and cloud computing to provide online services and develop Electronic Commerce (E-Commerce), which gives excellent support for the Iraqi economy and Iraqi citizens.

By our proposed strategies, the identification schema, as shown in Table 3, is intended to be adopted, which has the requirements of the Unified National Database and exclusive National Number (Unique IQ No.).This IQ number is aimed to be necessary to issue identity cards, passports, driving licenses, or whatever. This Schema will be more flexible and reliable than the previous schema and give more impedance against forgery approaches. Additionally, this has distinct Name and Father Name sections, unlike the previous schema in 
Table 1, which has three parts in the single Name Section (First Name, Father Name, and Grandfather Name) that will make the proposed schema have less complexity and confusion.

Table 3. The proposed Citizen Data Scheme

\begin{tabular}{|c|c|}
\hline Citizenship ID ( with Unique IQ No.) & Biometrics -Photograph \\
\hline $\begin{array}{c}\text { Resident Card ID (with Unique IQ } \\
\text { No.) }\end{array}$ & Biometric - Fingerprint \\
\hline $\begin{array}{c}\text { Name (The First Name)- } \\
\text { Surname(The Last Name) }\end{array}$ & \\
\hline Father Name & \\
\hline Gender & \\
\hline Mother Name & \\
\hline Marital Status & \\
\hline Name of Spouse & \\
\hline Full Address & \\
\hline Birth Date & \\
\hline Birth Place & \\
\hline
\end{tabular}

\section{Conclusion}

According to the case study of Iraq and the survey results, a total of 112 diverse e-Services has been proposed by Iraqi citizens. The essential e-Services have been highlighted by a list of e-Services provided in this paper. This study can be an essential step to expand e-Government and cloud computing functionaries in Iraq according to the citizen's views. Also, to analyze the social and technical barriers that impede the development of Iraqi e-Government and cloud computing.

This study can be outlooked as particular as it considerably determines the accessibility rate for the gateway of Iraqi e-Government and cloud computing and provides various prospective works and studies on the performance enhancements and transforms in the online service usage. This study as well shows to be necessary for the expansion and growth of future government diagrams for inspiring electronic transactions and encouraging investments in Iraq.

\section{Recommendations}

Simulating some cloud based network \& its protocols as well as e-Government can be done by new simulators as in CloudAnalyst, CloudSim, MATLAB, etc., to investigate many parameters of cloud and e-government in various Iraqi institutions. An additional research can be done in the area of Electronic Security (E-Security) based on unified identity database and modern face recognition techniques by comparing the input image with existing database images to display the citizen or resident information such as (name, surname, birth date, etc.) to detect the cases of counterfeiting and crimes in Iraq. E-Tourism and E-Investment in Iraq are possibly developed based on cloud and e-Government technologies. Internet of Thing (IoT) is a promising tool to enhance e-Services in Iraqi institutions in both governmental and private sectors. 
The e-Services related to citizen identification are particular concerns of national civilians. These civilians have many prospects from the government. The theory and analysis of this paper, to meet citizen prospects from the Iraqi government, should take into consideration a few more things. For example, allocating the available amount of budgets by the Ministry of Finance in Iraq for the proposed strategies in this paper. Some funds and consultancies can be utilized by Non-Governmental Organizations (NGOs). NGO Services Portal is a gateway for NGOs operated in Iraq, which can be intended as future work. NGOs can offer the required information and monetary services by connecting NGOs to the respective government departments and providing online information about the requisite service. The citizen's contribution should be more significant than before to reach the highest degree of use of their necessary online services.

\section{Acknowledgment}

The authors thank all Iraqi participants in the adopted survey of this study.

\section{References}

[1] E. SánchezJosé , J. Macías, "A set of prescribed activities for enhancing requirements engineering in the development of usable e-Government applications," Requirements Engineering , vol. 24, no. 2, pp .181203,2019.

[2] D. Putra, K. Jasmi, B. Basiron, M. Huda, A. Maseleno, K. Shankar, and N. Aminudin, "Tactical steps for e-government development," International Journal of pure and applied mathematics, vol. 119 no. 15 ,pp.2251-2258,2018.

[3] C. Yap , R. Ahmad , F. Newaz and C. Mason, "Continuous Use Intention of E-Government Portals the Perspective of Older Citizens," International Journal of Electronic Government Research, vol.15,no.1,pp. 1-16.,2019.

[4] L. Nag, "E-Government Applications," United Nations Asian and Pacific Training Centre for Information and Communication Technology for Development , no. 3,2010.

[5] OECD E-Government Studies, "E-Government for Better Government," available on http://www.oecd.org/gov/public-innovation/egovernmentforbettergovernment.html.

[6] Z. Fang, "E-Government in Digital Era:Concept, Practice, and Development," International Journal of The Computer, The Internet and Management, vol. 10, no.2, p 1-22, 2002.

[7] J. Bakker, "The benefits of cloud computing in IT intensive organizations," Erasmus University, 2012.

[8] A. Alhammadi, "A Knowledge Management Based Cloud Computing Adoption Decision Making Framework," PhD thesis, Staffordshire University,2016.

[9] L. Columbus, "Roundup Of Cloud Computing Forecasts And Market Estimates," Forbes Magazine, 2015.

[10] I. Martinus, M. Sharief, and B. Graul, "Government of Iraq e-government Strategy," USAID Publisher,2007.

[11] H. Abdulwahida, A. Mutaliba, S. Yusofa, and S. Alib, "Designing and Implementation Iraqi E-Government Front OfficeOnline System,"Journal of Knowledge Management, Economics and Information Technology, vol. 4, no. 2 ,pp. 1-11,April 2014.

[12] UN , “United Nations E-Government Survey," UN Publishing Section, New York,2010.

[13] Ministery of Science and Technology Website: http://most.gov.iq/index.php?name=News\&file=article\&sid=462.

[14] W. Jabbar, A. Ramasamy, and M. Othman, "CITIZEN IDENTIFICATION SYSTEM OF IRAQ: CHALLENGES AND BARRIERS IN ENABLING E-GOVERNMENT SERVICES," Proceedings of the 4th International Conference on Computing and Informatics, Malaysia,2013.

[15] General Directorate for Nationality/Iraq Website :http://www.iraqinationality.gov.iq/index_en.html. 
[16] UN , "United Nations E-Government Survey 2012: E-Government for the People,"UN Publishing Section, New York,2012.

[17] M. Wahsh, J. Dhillon, "An investigation of factors affecting the adoption of cloud computing for Egovernment implementation," IEEE Student Conference, pp. 323-328,2015.

[18] N. Mohan, A. Majeed, A. Saleh, and A. Mohain, "Using Cloud-Based Web Application for Universityes: A Case of University of Technology in Iraq," Advances in Computing, vol. 4,no. 1, pp.15-17,2014.

[19] H. Hashim ,Z. Hassan, "Factors That Influence The Users' Adoption Of Cloud Computing Services At Iraq Universities: An Empirical Study," Australian Journal of Basic and Applied Sciences, vol. 9,no. 27, pp.379-390,2015.

[20] M. Al-Attar, "A Proposed Cloud Computing Model for Iraqi's Engineering Colleges and Institutes," ZANCO Journal of Pure and Applied Sciences, vol. 28,no. 2,pp1-5,2016.

[21] M. Al-Ani, M. Ibrahim, "Efficient Virtual Universities via Cloud Computing Environmen," Journal of Emerging Trends in Computing and Information Sciences, vol. 3, no. 11,pp.1553-1559,2012.

[22] Z. Alazawi, S. Altowaijri, , R. Mehmood, and M. Abdljabar, "Intelligent disaster management system based on cloud-enabled vehicular networks," 11th International Conference on ITS Telecommunications, Russia, pp. 361-368,2011.

[23] M. Al-dabbagh, "Electronic Government in Iraq: Challenges of development and implementation," Swedish Business School at Orebro University, Project Work,2011.

[24] R . Hani, "Civil Society-civilized dialogue," Almhor newspaper, no. 3614,2012.

[25] A. Chatfield, O. Alhujran, "A Cross-Country Comparative Analysis of E-government Services Delivery among Arab Countries," Information Technology for Development ,vol. 15 no. 3,pp. 151-170,2009.

[26] P. Joshi, S. Islam. "E-Government Maturity Model for Sustainable E-Government Services from the Perspective of Developing Countries." Sustainability, vol. 10, no.6, p.1882, 2018.

[27] General Electronics Systems Company Website: http://www.gces-iq.com/

\section{Appendix 1}

E-Services in Iraq Survey

Survey Reason: e-Government and cloud computing services has been adopted in many countries, and its practice continually rising. E-Government and cloud computing these days permit nations like Iraq to hop over several technology generations to distribute competent and reasonable fee online services to citizens. At this point, the intention of e-Government practice has been done to estimate the required online services by the Iraqi citizens from the Government.

e-Government: It is described from the elemental standard of the information and communication technologies (ICTs) to offer government information and services through the web. Its activities can be used with state agencies, businesses, and citizens.

Cloud computing: It stands for a massive collection of different hardware, software, and other services, can be managed via the "cloud" environment. The complete resources of them can be accessed at anytime and anywhere as needed. Generally, the cloud provider sells his service based on pay-per-use. Specifically, it indicates that there is enormous flexibility in the implementation of these services as additional resources that are always accessible.

e-Service: It is a software piece that is part of e-Government. Its main goal is to computerize or partially computerize a specific managerial action. An application from a citizen can activate all e-Services. 
The services of e-Government are generally classified into Informative, Interactive, and Transactional types. Information e-Service means the mechanisms of the information of citizens to access through e-Government gateways as in weather forecasting and education-related information services. Interactive e-Services are the processes in which the citizens can use these online transactions to interact with Government agencies as in Recruitment Services and online Hajj applications. Transactional Service is the sale or purchase of services between individuals and governments or other public or private organizations employing e-Governments networks.

Please respond to all questions and inquiries as well as possible. You can insert more space if needed. It will be hugely valued for your suggestions and comments.

1. Explain your Internet usage frequency?
A) Every Day
B) Every Week
C) Every Month
D)Every Year

2. Do you think there is a big necessity for e-Services in Iraq? Why?

3. According to your opinion, are there any obstacles in such project implementation or development in Iraq?
A) Yes
B) No

4. If so, please indicate these obstacles?

5. Did you use any e-Services supplied by the Iraqi Government? If so, please indicate them below.

6. Explain your usage frequency of existing e-Services in Iraq?
A) Everyday B) Every Week
C) Every Month
D) Every Year E) When Needed
F) Never

7. Do you think that the Iraqi Government and cloud computing must put into practice new eServices for citizens?
A) Yes
B) $\mathrm{No}$

8. According to your awareness, state the leading Iraqi ministries in the e-Services field. Also, indicate the required online services to be appended in the e-Government and cloud computing according to your opinion.

9. What are your observations and ideas about the current e-Government services and cloud computing in Iraq?

10. Please, write down your personal details (Name, Nationality, Age, Gender, Profession, Residence Period in Iraq, Your Contact Details). 